\title{
EDUKASI PRILAKU CUCI TANGAN PAKAI SABUN (CTPS) DAN PEMBUATAN HAND SANITIZER UNTUK MENCEGAH PENYEBARAN COVID-19 PADA MASYARAKAT DI LINGKUNGAN BUMI BERKAT
}

\author{
Fitriyanti ${ }^{1}$, Revita Saputri ${ }^{11}$, Ratna Restapaty ${ }^{11}$ \\ 1)Program Studi S1 Farmasi,STIKES Borneo Lestari, Banjarbaru, Kalimantan Selatan,Indonesia \\ Corresponding author: Fitriyanti \\ E-mail: fitriyantihudari@gmail.com
}

Diterima 12 Oktober 2021, Direvisi 22 Oktober 2021, Disetujui 22 Oktober 2021

\begin{abstract}
ABSTRAK
Perilaku hidup sehat seperti mencuci tangan dengan sabun merupakan salah satu cara untuk meningkatkan kesadaran masyarakat tentang pemeliharaan kesehatan dan berperilaku hidup bersih dan sehat. Cuci tangan sering dianggap sebagai hal yang sepele di masyarakat, padahal cuci tangan dapat memberi kontribusi pada peningkatan status kesehatan masyarakat terutama di pandemi Covid 19. Hal ini dilakukan karena tangan sering sekali menjadi agen yang membawa kuman dan menyebabkan patogen berpindah dari satu orang ke orang lain baik sehingga dapat memindahkan bakteri, virus dan parasit. Selain masalah perilaku atau budaya Cuci Tangan Pakai Sabun (CPTS), tujuan kegiatan ini yang sering terjadi dan menjadi kendala dalam perilaku kesehatan pada masyarakat disebabkan karena kurangnya pengetahuan cara cuci tangan yang benar. Pengabdian masyarakat dilaksanakan di lingkungan RT 01 Bumi Berkat dengan mengedukasi CTPS dan mendemontrasikan pembuatan hand sanitizer. Pengetahuan tentang CTPS masyarakat diukur dengan kuesioner yang dibagikan kepada masyarakat. Hasil dari kegiatan pengabdian masyarakat bahwa pengetahuan dan kesadaran masyarakat Bumi Berkat meningkat dan lebih memahami dalam menerapkan Cuci Tangan Pakai Sabun (CTPS) dan penggunaan hand sanitizer karena lebih bangga dengan buatan sendiri. Sehingga perilaku Cuci Tangan Pakai Sabun (CTPS) dan penggunaan hand sanitizer sebelum dan sesudah beraktivitas menjadi budaya dan kebiasaan masyarakat untuk menekan penyebaran Covid-19 dan pemenuhan kebutuhan hidup sehat.
\end{abstract}

Kata kunci: cuci tangan; pakai sabun; covid-19

\begin{abstract}
Simple healthy living behaviors such as washing hands with soap are one way to raise public awareness about health maintenance and behaving in a clean and healthy life. Hand washing is often considered a trivial thing in the community, whereas hand washing can contribute to improving public health status, especially in the Covid-19 pandemic. This is done because the hands are often agents that carry germs and cause pathogens to move from one person to another both so as to move bacteria, viruses and parasites. In addition to behavioral problems or culture of Hand Washing Using Soap (CPTS), So the purpose which often occurs and becomes an obstacle in health behavior in the community due to lack of knowledge how to wash hands. Community service is carried out in the RT 01 Bumi Berkat environment by educating CTPS and demonstrating the manufacture of hand sanitizer. Knowledge of community CTPS is measured by questionnaires distributed to the community. The result of community service activities that knowledge and awareness of the people of Bumi Berkat increased and better understand in applying Hand Washing Using Soap (CTPS) and the use of hand sanitizer because it is more proud of homemade. So that the behavior of Hand Washing Using Soap (CTPS) and the use of hand sanitizer before and after activities become culture and habits of the community to suppress the spread of Covid-19 and meet the needs of healthy living.
\end{abstract}

Keywords: hand washing; using soap; covid-19

PENDAHULUAN

Corona Virus Disease 2019 atau Covid-19 adalah jenis penyakit baru yang disebabkan oleh infeksi Virus Severe Acute Respiratory Syndrome Coronavirus 2/
SARSCOV-2 (WHO,2020). Penyakit ini ditularkan melalui droplet (percikan) pada saat berbicara, batuk, dan bersin dari orang yang terinfeksi virus Corona. Penyakit tersebut dapat ditularkan melalui kontak fisik (sentuhan atau jabat tangan) dengan penderita serta 
menyentuh wajah, mulut, dan hidung oleh tangan yang terpapar virus Corona (Singhal, 2020). Pembatasan sosial (Social Distancing) berdampak terhadap pemenuhan kebutuhan pokok masyarakat. Upaya meminimalisir penularan Covid-19 serta menjamin kegiatan keagamaan di tempat beribadah, maka perlu dilakukan edukasi sebagai pengingat prilaku di masa new normal dengan CTPS sebagai salah satu protokol pengangan Covid-19.

CTPS merupakan salah satu prilaku PHBS, yang peningkatan harus menjadi tanggung jawab bersama dalam pencegahan Covid-19. PHBS (Perilaku Hidup Bersih dan Sehat) merupakan sekumpulan perilaku yang dipraktikkan atas dasar kesadaran sebagai hasil pembelajaran yang menjadikan seseorang, keluarga, kelompok atau masyarakat agar mampu menolong dirinya sendiri (mandiri) di bidang kesehatan dan berperan aktif dalam mewujudkan kesehatan masyarakat (Peraturan Menteri Kesehatan Republik Indonesia Nomor 2269). Penerapan prilaku tersebut diharapkan dapat diikuti oleh peningkatan sikap dan perilaku masyarakat untuk menerapkannya secara mandiri. Oleh sebab itu, kemandirian yang telah terdapat dalam diri masyarakat perlu didukung oleh keadaan lingkungan di sekitarnya. Hal tersebut menjadi asumsi bahwa perilaku cuci tangan pakai sabun yang merupakan suatu upaya yang mudah, sederhana, murah, dan berdampak besar bagi pencegahan penyakit Covid-19 belum menjadi kebiasaan pada masyarakat yang rentan penularannya terhadap penyakit.

\begin{tabular}{rlr}
\multicolumn{2}{c}{ Berdasarkan } & penelitian bahwa \\
sebanyak $52,7 \%$ & yang & memiliki
\end{tabular} pengetahuan baik dan 56,1\% yang mempunyai sikap mendukung terhadap Perilaku Cuci Tangan Pakai Sabun, (CTPS), sedangkan $56,1 \%$ responden yang berperilaku Cuci Tangan Pakai Sabun (Fajar dan Misnaniarti, 2011). Berdasarkan uraian di atas hal ini dipengaruhi oleh rendahnya pengetahuan dan kesadaran masyarakat tersebut terhadap perilaku Cuci Tangan Pakai Sabun. Perkembangan jumlah kasus penyebaran Covid-19 secara kumulatif di Kalimantan Selatan berjumlah 8.200 kasus. Resiko penyebaran Covid-19 di era new normal, salah satu yaitu kegiatan ibadah di masjid. Oleh karena itu, perlunya di laksanakan kegiatan pengabdian masyarakat yang berjudul "Penerapan prilaku Cuci Tangan Pakai Sabun (CTPS) dan pembuatan Hand Sanitizer diBumiberkat RT 01 Banjarbaru" dengan harapan peningkatan penerapan dan perilaku masyarakat CTPS secara mandiri setelah dan sebelum beraktivitas.

Permasalahan yang dialami masyarakat antara lain; masyarakat belum memahami pentingnya dan tata cara CTPS sesuai dengan standar kesehatan dan belum meningkatkan penerapan prilaku CTPS secara mandiri untuk pencegahan menyebarnya Virus Covid-19. Pelaksanaan pengabdian masyarakat ini bertujuan untuk mengedukasi masyarakat mengenai tata cara CTPS sesuai dengan standar kesehatan untuk pencegahan menyebarnya Virus Covid-19 dan untuk meningkatkan penerapan prilaku CTPS masyarakat secara mandiri di masa New Normal Covid-19.

\section{METODE}

Kegiatan Pengabdian Masyarakat dilaksanakan pada masyarakat Kelurahan Bumi Berkat Banjarbaru sebanyak 33 peserta, 3 dosen dan 10 mahasiswa. Kegiatan pengabdian dalam bentuk memberikan edukasi/ informasi tentang edukasi penerapan prilaku Cuci Tangan Pakai Sabun (CTPS) untuk mencegah penyebaran Covid-19, dilaksanakan dalam 2 bentuk yaitu kegiatan pertama adalah memberikan edukasidengan memaparkan pencegahan penularan Covid19 dengan penerapan prilaku CTPS dan pembuatan hand sinitizer. Metode pemaparan terori dengan presentasi materi yang dikemas menarik dalam slide power poin dan mendemontrasikan pembuatan Hand Sanitizer. Media visual dalam kegiatan pengabdian masyarakat lainnya berupa poster Cuci Tangan Pakai Sabun (CTPS). Pengukuran pengetahuan tentang Prilaku Cuci Tangan Pakai Sabun (CTPS) diidentifikasi dengan hasil perhitungan kuesioner yang dibagikan pada masyarakat.

\section{HASIL DAN PEMBAHASAN}

Kegiatan Pengabdian kepada Masyarakat, ada 2 kegiatan yang dilakukan yaitu; 1) mengedukasi perilaku Cuci tangan Pakai sabun (CTPS) serta Gerakan Cuci Tangan yang Benar dan 2) pembuatan hand sanitizer.

Kegiatan pengabdian masyarakat ini merupakan integrasi hasil dari penelitian CTPS sebelumnya. Berdasarkan penelitian bahwa sebanyak $52,7 \%$ yang memiliki pengetahuan baik dan $56,1 \%$ yang mempunyai sikap mendukung terhadap Perilaku Cuci Tangan Pakai Sabun, (CTPS), sedangkan $56,1 \%$ responden yang berperilaku Cuci Tangan Pakai Sabun (Fajar dan Misnaniarti, 2011). Berdasarkan uraian di atas hal ini dipengaruhi oleh rendahnya 
pengetahuan dan kesadaran masyarakat tersebut terhadap perilaku Cuci Tangan Pakai Sabun.

Tahap pertama kegiatan pengabdian masyarakat ini yakni pemberian edukasi Perilaku Hidup Bersih dan Sehat (PHBS) melalui kegiatan pengabdian masyarakat dengan topik Cuci Tangan Pakai Sabun (CPTS) dan demontrasi pembuatan Hand Sinitizer; dengan peserta sebanyak 33. Acara berjalan lancar dan peserta mengikuti dengan baik dengan tetap mematuhi protokol kesehatan,seperti pada gambar 1 berikut.

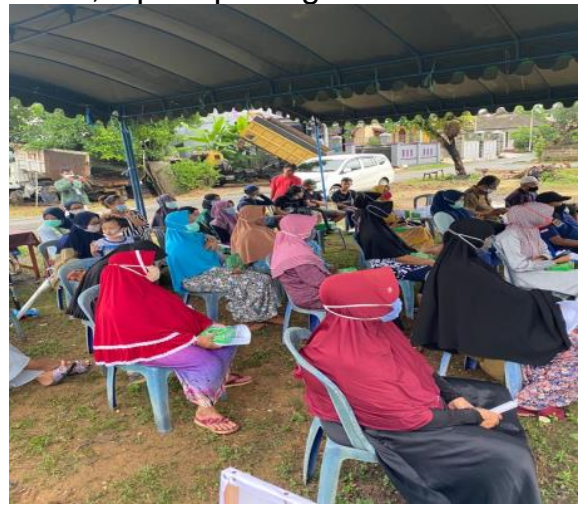

Gambar 1. Antusias warga dalam kegiatan pengabdian masyarakat

Gambar 1 di atas menunjukkan secara visual antusiame masyarakat sangat tinggi dengan memperhatikan tahapan Cara CTPS yang benar yakni adalah menggosok telapak tangan secara bersamaan, menggosok punggung keduatangan, jalinkan kedua telapak tangan lalu digosok-gosokkan, tautkan jari-jari antarakedua telapak tangan secara berlawanan, gosok ibu jari secara memutar dilanjutkan dengan daerah antara jari telunjuk danibu jari secara bergantian, gosok kedua pergelangan tangan dengan arah memutar bilas dengan air dan keringkan. Hal terpenting dalam CTPS bukan berapa lama waktu mencuci tangan, tetapi cara mencuci tangannya (Kemenkes RI, 2014). Seperti yang tergambarkan di poster yang di bagikan kepada masyrakat, seperti pada gambar 2 berikut.

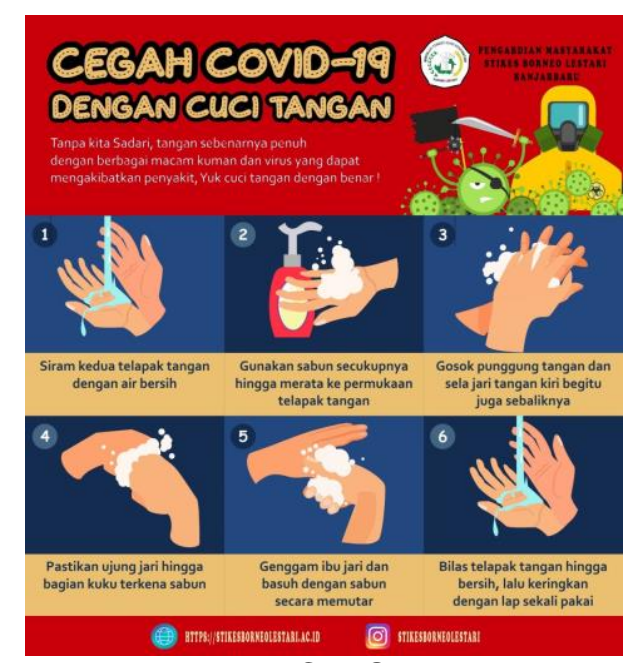

Gambar 2. Poster CTPS yang ditempel di Wastafel portabel dan di bagikan untuk masyarakat

Cuci tangan pakai sabun sesering mungkin setiap akan mulai dan akhiri aktivitas perlu kesadaran dalam diri masyarakat. Hal tersebut sesuai dengan hasil penelitian bahwa apabila dalam beraktivitas tidak mencuci tangan menggunakan sabun, dapat menularkan infeksi pada diri sendiri terhadap bakteri dan virus dengan memegang bagian hidung, mata dan mulut. Selain itu juga dapat menyebarkan atau menularkan bakteri kepada orang lain (Risnawati, 2016).

Antusias masyarakat ditunjukkan dengan aktif dalam sesi taanya jawab, pertanyaan terkait Covid- 19 dan CTPS. Pertanyaan antara lain; 1) seberapa efektif cuci tangan pakai sabun dibanding hand sanitizer, 2) jenis sabun apa yang lebih efektif membunuh virus, 3) bagaimana cara membuat pembuatan hand sinitizer secara mandiri di rumah apakah bahandan alat mudah didapatkan?. Jumlah masyarakat RT 01. Bumi Berkat yang berpastisipasi sebagai peserta ditunjukkan pada tabel 1 berikut

Tabel 1. Distribusi Jumlah Persentasi Peserta.

\begin{tabular}{ccc}
\hline $\begin{array}{c}\text { Kategori } \\
\text { Jenis kelamin }\end{array}$ & Jumlah & Presentasi \\
\hline Perempuan & 20 & $66 \%$ \\
\hline Laki-laki & 13 & $44 \%$ \\
\hline
\end{tabular}

Tujuan kegiatan salah satunya yakni untuk meningkatkan pengetahuan dan kesadaran sehingga dapat mentransformasi, mengembangkan, serta menyebarluaskan ilmu pengetahuan dan teknologi melalui kegiatan pengabdian masyarakat. Tahap kedua kegiatan pengabdian masyarakat ini yakni pembuatan hand sanitizer.

Hand sanitizer merupakan alternatif apabila disekitar tempat aktivitas tidak terdapat air mengalir dan sabun untuk cuci tangan, salah satu cara yang dapat digunakan yaitu 
dengan menggunakan pembersih tangan (hand sanitizer). Gel hand sanitizer umumnya terbuat dari bahan yang mengandung alkohol seperti Etil Alkohol yang berfungsi sebagai antiseptik. Hand sanitizer dengan kadar alkohol $70 \%$ efektif dalam membunuh bakteri dan aman, dengan konsentrasi yang besar maka mikroorganisme dapat dibunuh (Rezky, 2016). Demontrasi pembuatan hand sanitizer pada kegiatan pengabdian masyarakat ini ditunjukkan gambar 3 berikut.

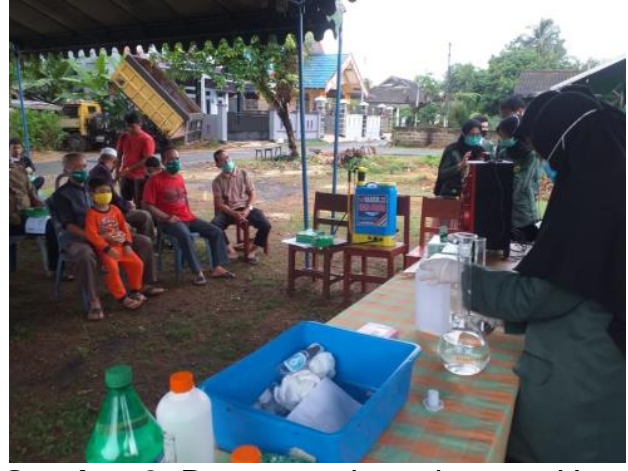

Gambar 3. Demontrasi pembuatan Hand sinitizer

Gambar 3 di atas menunjukkan secara visual Tim dosen dan mahasiswa mendemontrasikan cara membuat hand sinitizer. Antusias masyarakat sangat tinggi karena bahan dan alat mudah untuk didapatkan.

Berdasarkan data akhir satgas Covid-19 kota Banjarbaru tahun 2021 bahwa Kelurahan Sungai Besar adalah daerah tertinggi angka kejadian Covid-19 dibanding 3 kelurahan yang lain di Kecamatan Banjarbaru Selatan, sehingga perlu dilakukan penyuluhan terkait cara pencegahan Covid-19 salah satunya dengan penerapan cuci tangan pakai sabun dengan 6 langkah sehingga diharapkan efektif menghambat kuman dan virus. Selain penyuluhan tentang pencegahan Covid-19, kegiatan pengabdian masyarakat dilanjutkan dengan pembuatan hand sinitizer. Sehingga warga di lingkungan RT.01 Kelurahan Sungai Besar dapat secara mandiri untuk penerapkan CTPS dan pembuatan hand sinitizer.

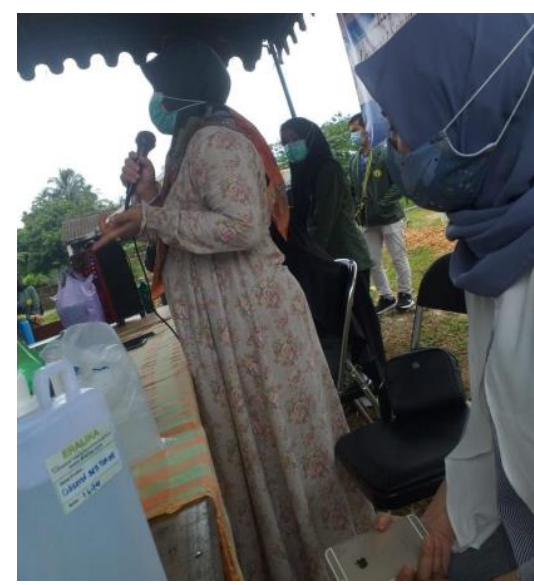

Gambar 4. Penjelasan materi oleh Tim dosen pengabdian masyarakat

Pengetahunan masyarakat tentang prilaku cuci tangan dan pembuatan hand sanitizer di ukur dari kuesioner yang dibagikan dalam kegiatan pengabdian masyarakat, hasil analisis pada gambar tabel berikut.

Tabel 2. Distribusi Frekuensi Pemahaman Peserta.

\begin{tabular}{ccc}
\hline Pemahaman & Frekuensi & Presentasi \\
\hline Baik & 26 & $78 \%$ \\
\hline Cukup & 5 & $15 \%$ \\
\hline Kurang & 2 & $6 \%$ \\
\hline
\end{tabular}

Tabel 2. di atas menunjukkan hasil evaluasi pemahaman materi yang diterima oleh masyarakat RT 01 dengan tingkat pemahaman baik dengan persentase $78 \%$, hal ini menunjukkan bahwa mereka mampu menerima pemberian materi. Sebagian besar masyarakat belum mengikuti penyuluhan mengenai pentingnya Cuci Tangan Pakai Sabun (CPTS) \& pembuatan Hand Sinitizer. Aktivitas harian masyarakat beresiko penyebaran Covid-19, karena sebagian besar masyarakat Bumi berkat adalah pekerja dan pedagang.

Pentingnya Cuci Tangan Pakai Sabun (CPTS) \& pembuatan Hand Sinitizer, diharapkan kegiatan dengan topik serupa secara intensif dilakukan dan melalui kegiatan pengabdian masyarakat sehingga masyarakat secara mandiri dan rutin. Hal ini dapat menekan angka penyebaran Covid-19 di wilayah Banjarbaru. 


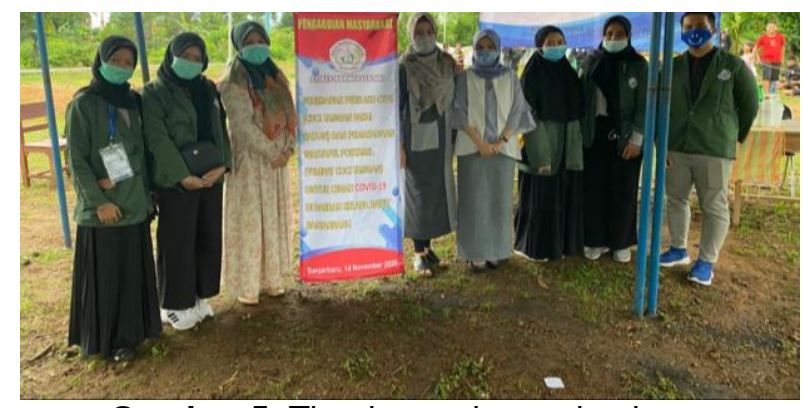

Gambar 5. Tim dosen dan mahasiswa kegiatan Penabdian mayarakat.

\section{SIMPULAN DAN SARAN}

Kegiatan Pengabdian Masyarakat dengan topik Pentingnya Cuci Tangan Pakai Sabun (CPTS) \& pembuatan Hand Sinitizer, dalam upaya pencegahan penyebaran Covid19 di Bumiberkat Kel. Sungai Besar menghasilkan peningkatan pengetahuan dan kesadaran masyarakat dalam menerapkan Cuci Tangan yang baik dan benar sebelum dan sesudah beraktivitas. Sehingga perilaku Cuci Tangan Pakai Sabun (CTPS) dan penggunaan hand sanitizer menjadi budaya dan kebiasaan masyarakat untuk menekan penyebaran Covid-19 dan pemenuhan kebutuhan hidup sehat.

Diharapkan berdasarkan hasil meningkatnya kesadaran masyarakat untuk menekan penyebaran Covid-19 perlu dilakukan kegiatan lanjutan untuk kegiatan pengabdian masyarakat secara intensif dengan melibatkan masyarakat dalam jumlah yang lebih besar dengan melibatkan semua usia (mulai dari anak usia dini sampai usia lansia). Penyampaian materi berbasis digital dibagikan dalam tayangan sosial media sehingga materi terdistribusikan untuk masyarakat secara luas.

\section{UCAPAN TERIMAKASIH}

Penulis berterimakasih kepada LPPM dan mahasiswa STIKES Borneo Lestari yang telah membantu pelaksanaan kegiatan Pengabdian bagi masyarakat Bumi Berkat di Kelurahan Sungai Besar- Banjarbaru

\section{DAFTAR RUJUKAN}

Fajar N.A dan Misnaniarti. (2011). Hubungan Pengetahuan dan Sikap Terhadap Perilaku Cuci Tangan Pakai Sabun pada Masyarakat di Desa Senuro Timur. Jurnal Pembangunan Manusia 5:1. Pemprov Sumatra Selatan; Balitbang Daerah

Peraturan Menteri Kesehatan Republik Indonesia. (2011). Pedoman Pembinaan Perilaku Hidup Bersih dan
Sehat

Nomor 2269/MENKES/PER/XI/2011 (PHBS)

Reski, A.N. (2016). Perbandingan Daya Bunuh Produk Handsanitizer Gel Berbasis Alkohol Dan Triclosan Terhadap Bakteri Tangan. Tesis, FKIP Universitas Pasundan. Bandung.

Risnawaty, Gracia. 2016. Faktor Determinan Perilaku Cuci Tangan Pakai Sabun (CTPS) Pada Masyarakat di Tanah Kalikedinding. Jurnal Promkes, Vol. 4, No. 1 Juli $2016 . \quad$ Departemen Administrasi dan Kebijakan Kesehatan Fakultas Kesehatan Masyarakat Universitas Airlangga.

Singhal, T. (2020). A Review of Coronavirus Disease -2019 (COVID -19). The Indian Journal of Pediatrics, 87(4): 281 -286 .

WHO. (2020). Coronavirus disease (COVID 19) Situation Report -121 . https://www.who.int/docs/default source/coronaviruse/ Diakses 20 Mei 2020. 